\title{
Luffa Sponge Gourd Production Practices for Temperate Climates
}

\author{
Jeanine M. Davis ${ }^{1}$ \\ Department of Horticultural Science, North Carolina State University, Mountain \\ Horticultural Crops Research and Extension Center, 2016 Fanning Bridge \\ Road, Fletcher, NC 28732
}

Additional index words. loofa, loofah, Luffa aegyptiaca, Luffa cylindrica, cultural practices, flowering, yields

\begin{abstract}
The objective of 2 years of field studies was to begin development of a luffa sponge gourd (Luffa aegyptiaca Mill.) production system for a cool, temperate climate by studying the effects of planting date, planting method, in-row spacing $(30.5,61$, and $91 \mathrm{~cm})$, and pruning techniques on yield and quality of luffa sponge gourds. High yields of mature gourds were obtained when transplants were field-set as soon as the danger of frost had past. Highest marketable yields were obtained when plants were spaced $30.5 \mathrm{~cm}$ apart in the row and the first four lateral shoots were removed. Plants spaced $91 \mathrm{~cm}$ apart produced gourds with the largest diameter, whereas plants with $30.5-\mathrm{cm}$ in-row spacing produced the highest yields of gourds with bath sponge diameters $(5.1-7.6 \mathrm{~cm})$. Plants spaced $91 \mathrm{~cm}$ apart and topped at node six obtained high fiber density, strong fibers, and excellent visual appeal, but low yields. Yields were competitive with yields obtained in warmer climates.
\end{abstract}

Luffa sponge gourds are tropical and subtropical members of the Cucurbitaceae and have been cultivated for centuries in the Middle East and India, China, Japan, and Malaysia (Porterfield, 1955). The plant is an annual vine with tendrils and large, cylindrica pepo (berry) fruit that are edible when young (Okusanya et al., 1981). The mature, dry fruit consists of a hard shell surrounding a stiff, dense network of cellulose fibers (sponge), adapted for support and dispersal of hundreds of flat, smooth, black seeds (Shah et al., 1980).

Using luffa sponges for personal hygiene and household cleaning is common in many countries. In the United States, the demand for luffa sponge products for skin care is increasing. Currently, most luffa sponge gourds are produced in tropical or semitropical environments such as Taiwan, Korea, El Salvador, Guatemala, and Colombia (Davis and DeCourley, 1993). Wholesale prices of $\$ 0.40$ to $\$ 0.50$ per sponge (Davis and DeCourley, 1993; D. Brinker, personal communication) coupled with the rising demand for luffa products and a desire for new, high-value crops have stimulated interest among some North American growers.

\footnotetext{
Received for publication 12 July 1993. Accepted for publication 3 Nov. 1993. This research 7695-7643 was supported in part by North Carolina Agricultural Research Service, Raleigh, and the U.S. Dept. of Agriculture Special Grant P.L. 89-106. I gratefully acknowledge materials supplied by Roberts Irrigation Products, seeds supplied by John Ayres, and technical assistance from George Cox. Use of trade names does not imply endorsement of the products named nor criticism of similar ones not named. The cost of publishing this paper was defrayed in part by the payment of page charges, Under postal regulations, this paper therefore must be hereby marked advertisement solely to indicate this fact.

'Assistant Professor.
}

Ample information on growing luffa sponge gourds is available for home gardeners (Johnson, 1984; Stephens, 1988; Whitaker, 1977), but the recommended practices are not necessarily appropriate for commercial producers. Most research relevant to commercial luffa production has been conducted in the tropical and subtropical climates of West Africa and India (Dubey, 1983; Okusanya, 1978, 1983a, 1983b; Okusanya et al., 1981, 1988; Okusanya and Lakanmi, 1985; Omini and Hossain, 1987; Singh et al., 1976). Only a few studies have been conducted in temperate climates (Bai et al., 1985; Ko et al., 1978). Okusanya (1978) suggested that the natural absence of luffa outside tropical and subtropical regions was due, in part, to poor germination at low temperatures and a need for high light intensity and temperature for optimum plant growth.

Luffa sponge gourd plants are similar in growth habit to cucumbers (Cucumis sativus L.). Substantial yield increases can be obtained by training cucumbers to a vertical trellis rather than growing them on the ground (Hanna et al., 1987; Russo et al., 1991). If luffa gourds contact the ground, fruit rot, discolored sponges, and misshaped gourds may result; thus, luffa plants also benefit from being trained to trellises (Porterfield, 1955; Sinnott and Bloch, 1943). Results from three on-farm tests in western North Carolina in 1989 demonstrated the benefits of using black polyethylene mulch and drip irrigation for luffa gourd production (J.M.D., unpublished).

Most luffa cultigens are monoecious. Staminate flowers develop in an inflorescence, whereas distillate flowers develop singly or in association with a staminate inflorescence (Takahashi, 1980). As with most monoecious cucurbits, the lower nodes of luffa usually bear only staminate inflorescences, followed by nodes having both staminate inflorescences and distillate flowers, which are followed by solitary distillate flowers at the uppermost nodes (Omini and Hossain, 1987). Increasing the number of distillate flowers would increase yield potential (Omini and Hossain, 1987) and hasten maturity-important factors for a tropical plant grown in a temperate climate. Two greenhouse studies in 1989 and 1990 indicated that removing the first four to six lateral shoots would hasten distillate flower development (J.M.D., unpublished). In contrast, preliminary research in Missouri indicated that most fruit is set on lateral and sublateral shoots and that pinching out the main stem encouraged early fruit set (C.D. DeCourley, personal communication).

My objective was to begin development of a luffa production system for a cool, temperate climate by studying the effects of planting date, planting method, in-row spacing, and pruning techniques on yield and quality of luffa sponge gourds.

\section{Materials and Methods}

Two studies were conducted in Fletcher, N.C., on a submountain plateau with an elevation of $\approx 631 \mathrm{~m}$ at lat. $35^{\circ} 26^{\prime} \mathrm{N}$, long. $82^{\circ} 34^{\prime} \mathrm{W}$. This region has an average of 188 frost-free days, a mean annual daily temperature of $13 \mathrm{C}$, and an average annual rainfall of $1470 \mathrm{~mm}$ (Byrd, 1988).

In 1989, the influence of three planting dates (29 May, 12 June, and 26 June) and two planting methods (direct seeding vs. transplanting) were examined as a factorial in a randomized complete-block design with four replications. Plots consisted of three 6-m rows spaced $1.5 \mathrm{~m}$ apart, center to center. Data were collected from the center rows; outer rows served as guard rows.

Seeds from high-quality luffa sponges were obtained from China through J.A. Ayers (Earth Products, Lapeer, Mich.). Transplants were produced in the greenhouse in plastic flats with $5 \times 5-\mathrm{cm}$ cells. Seed were soaked in water for $24 \mathrm{~h}$ and sown, two seeds per cell, in a soilless peat-bark mix on 28 Apr., 11 May, and 24 May. Plants were watered daily with $100 \mathrm{mg} \mathrm{N} /$ liter as $20 \mathrm{~N}-4.4 \mathrm{P}-16.6 \mathrm{~K}$.

The experiment was conducted on a Delanco loam (fine loamy, mixed, mesic, Aquic Hapludults). Okusanya (1983b) suggested that L. aegyptiaca grew best in a neutral $\mathrm{pH}$ soil with high fertility, particularly $\mathrm{N}$ and $\mathrm{P}$. Therefore, on 19 May, 84N-291P-134K (in $\mathrm{kg} \cdot \mathrm{ha}^{-1}$ ) and $1121 \mathrm{~kg}$ lime/ha (for a $\mathrm{pH}$ of 6.5 ) were broadcast-applied to the soil and incorporated. Beds were shaped to $15 \mathrm{~cm}$ high $\times 1 \mathrm{~m}$ wide, and a black polyethylene mulch $(0.08 \mathrm{~mm}$ thick) and drip-irrigation tape (Ro-Drip, 46$\mathrm{cm}$ emitter spacing; Roberts Irrigation, San Marcos, Calif.) were applied in a single operation. Holes were punched $46 \mathrm{~cm}$ apart in the polyethylene mulch using a bulb planter. On each planting date, seed (that had been soaked in water for $24 \mathrm{~h}$ ) were sown two per hole ( 25 $\mathrm{mm}$ deep) or 4-week-old transplants were set out. A $1.5-\mathrm{m}$-tall vertical trellis system was constructed of $10 \times 10-\mathrm{cm}$ wood posts with a $2.5-\mathrm{cm}$-diameter steel pipe as the horizontal 
top wire. Individual strings were suspended over each plant to help train plants to the top of the trellis. Direct-seeded plants were thinned to one plant per hole 3 weeks after planting. The first four lateral shoots were pruned from all plants, and plants were trained to the strings as needed. A hive of honey bees was positioned near the field at first bloom. Pest problems were minimal; fungicides and insecticides registered for gourds were applied as needed for powdery mildew (Erysiphe spp.) and cucumber beetle [spotted, Diabrotica undecimpunctata howardi Barber and striped, Acalymma vittata (Fabricius)] control. On six occasions in July and August, $28 \mathrm{~kg} \mathrm{~N} / \mathrm{ha}$ as $20 \mathrm{~N}-4.4 \mathrm{P}-16.6 \mathrm{~K}$ was applied through the drip-irrigation system.

On 5 and 18 July, flowers and fruit on 91$\mathrm{cm}$ lengths of row (about two plants) per plot were counted. A heavy frost killed the foliage on 30 Oct. On 3 Nov. all dried gourds (fruit) were harvested from the plots (first harvest). Remaining gourds were left to dry in the field until 4 Dec., when all dried gourds were harvested (second harvest). Any gourds not dry at that time were considered immature and left in the field. Dried gourds were soaked for 5-10 min until the fibrous interior (sponge) separated easily from the hardened skins. Sponges were air-dried and seeds were removed by shaking.

In 1990, three in-row spacings $(30.5,61$, and $91 \mathrm{~cm}$ ) and three pruning treatments (no pruning, removing the first four lateral shoots, and topping the main stem at node six) were examined as a factorial in a randomized complete-block design with four replications. Plots consisted of three $6-\mathrm{m}$ rows spaced $1.5 \mathrm{~m}$ apart, center to center. Data were collected from only the center rows.

Seeds for this study were saved from gourds produced in 1989. Transplants were produced as previously described with seeds sown on 17 Apr. All cultural practices were the same as described for 1989. On 16 May, $84 \mathrm{~kg} \mathrm{~N} / \mathrm{ha}$ and $257 \mathrm{~kg}$ each of $\mathrm{P}$ and $\mathrm{K}$ per hectare were broadcast-applied to the soil and incorporated. Soil pH was 6.5. On 1 June, 6-week-old transplants were set out. Plants were pruned and trained as required in the 6 weeks following planting. A total of $22 \mathrm{~kg} \mathrm{~N} / \mathrm{ha}$ as $20 \mathrm{~N}-4.4 \mathrm{P}-$ $16.6 \mathrm{~K}$ was applied through the drip-irrigation system on six occasions in August and September. Dried gourds were harvested on 17 Oct., 14 Nov., and 10 Dec.

A subjective evaluation system was used to compare sponges for overall fiber density, fiber strength, and visual appeal. Sections (76 $\mathrm{mm}$ square) were cut from the outer wall of representative gourds for analysis. Overall fiber density was rated on a scale of 1 to 5 (1 $=$ very loose, open weave of fibers through which newspaper print could be read; $5=$ very close woven fibers that allowed little light to penetrate). Sponge strength was rated on a scale of 1 to 5 and determined by holding the sponge near its center with hands $\approx 10 \mathrm{~cm}$ apart and pulling and twisting: $1=$ crumbled easily, $2=$ did not crumble but could be pulled apart, $3=$ took some effort to pull apart, $4=$ was very difficult to pull apart, and $5=$ could not be pulled apart. Visual appeal was rated on a scale of 1 to 5 ( $1=$ poor with loose, broken, uneven fibers; 3 = good with fairly close woven, even fibers; $5=$ excellent with close woven, even fibers and a smooth finish). Data were analyzed by an analysis of variance and protected least significant difference (MSTAT-C, Michigan State Univ.).

\section{Results and Discussion}

In 1989, using transplants resulted in a better plant stand than did direct-seeded plants (data not shown). Regardless of planting date, $99 \%$ to $100 \%$ of the transplants survived. In contrast, the highest stand with direct-seeding was $74 \%$, obtained at the 29 May seeding. Direct seeding on 12 and 26 June resulted in plant stands of $68 \%$ and $63 \%$, respectively. These germination rates are similar to those reported in a study by Okusanya (1978) in which the highest germination rates $(70 \%$ to $72 \%)$ were obtained when luffa seeds were buried 10-25 $\mathrm{mm}$ deep in the soil and exposed to alternating temperatures of 21 and $31 \mathrm{C}$.

Only a few of the 29 May and 12 June transplants had flowered by 8 July (e.g., 29 May transplants had an average of 0.9 pistillate flowers and 0.3 staminate inflorescences). Contrary to reports in which pistillate flowers

Table 1. Influence of planting date and planting method on sex expression of flowers and number of fruit of luffa sponge gourds. ${ }^{2}$

\begin{tabular}{|c|c|c|c|c|}
\hline & & Staminate $^{y}$ & Pistillate $^{x}$ & $\overline{\text { Fruit }}$ \\
\hline Planting date & Planting method ${ }^{w}$ & \multicolumn{3}{|c|}{ No./91 cm of row ${ }^{v}$} \\
\hline 29 May & $\mathrm{T}$ & 7.8 & 0.3 & 6.5 \\
\hline 12 June & $\mathrm{T}$ & 4.8 & 1.8 & 4.0 \\
\hline 26 June & $\mathrm{T}$ & 0 & 0.3 & 0.8 \\
\hline 29 May & D & 0.3 & 1.5 & 2.8 \\
\hline 12 June & $\mathrm{D}$ & 0 & 0 & 0 \\
\hline 26 June & $\mathrm{D}$ & 0 & 0 & 0 \\
\hline $\mathrm{LSD}_{0.05}$ for interaction & & 2.6 & 1.5 & NS \\
\hline \multicolumn{5}{|l|}{ Significance } \\
\hline Planting method & & $* *$ & NS & $* *$ \\
\hline Planting date & & $* *$ & NS & ** \\
\hline Interaction & & $* *$ & * & NS \\
\hline
\end{tabular}

${ }^{7}$ Data taken on 18 July.

'Inflorescences.

${ }^{\text {xSolitary flowers. }}$

${ }^{\mathrm{w}} \mathrm{T}=$ transplant; $\mathrm{D}=$ direct seed.

"Due to intertwining of vines, this is about two plants.

Ns, *, "* Nonsignificant or significant at $P \leq 0.05$ or 0.01 , respectively.

Table 2. Influence of planting date and planting method on first harvest, total yield, and size of luffa sponge gourds.

\begin{tabular}{|c|c|c|c|c|}
\hline \multirow[b]{2}{*}{ Main effect } & \multicolumn{2}{|c|}{ No. gourds/ha (1000s) } & \multicolumn{2}{|c|}{ Avg gourd size $(\mathrm{cm})^{x}$} \\
\hline & First harvest & Total harvest & Length & Diam \\
\hline \multicolumn{5}{|l|}{ Planting method } \\
\hline Transplant & 33.5 & 82.5 & 35.9 & 8.1 \\
\hline Direct seed & 12.1 & 68.0 & 35.5 & 7.6 \\
\hline \multicolumn{5}{|l|}{ Planting date } \\
\hline 29 May & 33.8 & 82.6 & 36.6 & 8.3 \\
\hline 12 June & 21.9 & 74.4 & 35.7 & 7.8 \\
\hline 26 June & 12.6 & 68.8 & 34.8 & 7.4 \\
\hline $\mathrm{LSD}_{005}$ & 7.5 & 7.1 & NS & 0.1 \\
\hline \multicolumn{5}{|l|}{ Significance } \\
\hline Planting method & $* *$ & $* *$ & NS & $* *$ \\
\hline Planting date & $* *$ & $* *$ & NS & $* *$ \\
\hline Interaction & NS & NS & NS & NS \\
\hline
\end{tabular}

From total harvest.

${ }_{N s, *, * *}$ Nonsignificant or significant at $P \leq 0.05$ or 0.01 , respectively. 
can be made from a particular sponge. Neither planting date nor planting method had any effect on average sponge length (Table 2); $62 \%$ of sponges were $30.5-45.7 \mathrm{~cm}$ long, and $<5 \%$ were $<15.2 \mathrm{~cm}$ long. Average sponge diameter, however, was greater for sponges from transplants than direct-seeded plants and from the earliest planting date. Largediameter sponges can be split open longitudinally and flattened into sheets for manufacturing mitts, pads, and washcloths. Of the sponges

Table 3. Influence of planting date and planting method on diameter of luffa sponge gourds.

\begin{tabular}{|c|c|c|c|}
\hline \multirow{3}{*}{$\begin{array}{l}\text { Planting } \\
\text { date }\end{array}$} & \multirow{3}{*}{$\begin{array}{l}\text { Planting } \\
\text { method }^{z}\end{array}$} & \multicolumn{2}{|c|}{ Percent total yield } \\
\hline & & \multicolumn{2}{|c|}{ Gourd diam $(\mathrm{cm})$} \\
\hline & & $5.1-7.6$ & $7 . \overline{7-10.2}$ \\
\hline $\overrightarrow{29 \text { May }}$ & $\bar{T}$ & 32 & 53 \\
\hline 12 June & $\mathrm{T}$ & 38 & 54 \\
\hline 26 June & $\mathbf{T}$ & 53 & 39 \\
\hline 29 May & D & 35 & 56 \\
\hline 12 June & $\mathrm{D}$ & 57 & 32 \\
\hline 26 June & D & 57 & 31 \\
\hline $\operatorname{LSD}_{0.05}{ }^{y}$ & & 10 & 13 \\
\hline Significance & & & \\
\hline $\begin{array}{l}\text { Planting } \\
\text { date }\end{array}$ & & $* *$ & * \\
\hline $\begin{array}{l}\text { Planting } \\
\text { method }\end{array}$ & & $* *$ & $* *$ \\
\hline Interaction & & * & * \\
\hline
\end{tabular}

${ }^{\mathrm{z}} \mathrm{T}=$ transplant; $\mathrm{D}=$ direct seed.

yFor interaction.

".** Significant at $P \leq 0.05$ and 0.01 , respectively. from the first planting date, $>50 \%$ were in the large-diameter $(7.7-10.2 \mathrm{~cm})$ category, regardless of planting method (Table 3). By the third planting date, only $39 \%$ or $31 \%$ of sponges from transplanted plants or direct-seeded plants, respectively, fit that category. Luffa sponges sold as bath sponges are commonly $15-30 \mathrm{~cm}$ long and $5.1-7.6 \mathrm{~cm}$ in diameter. In contrast to the large-diameter sponges, the percentage of sponges that fit the bath-sponge diameter category increased with later planting dates.

Ko et al. (1978) reported that gourd yields increased as in-row spacing decreased (Table 4). The closest in-row spacing $(30.5 \mathrm{~cm})$ resulted in the highest yields for two of the three harvests and the total season harvest. Yields obtained in this study with the $61-\mathrm{cm}$ in-row spacing were $\approx 1.25$ times greater than those reported by Ko et al. (1978) for a $60-\mathrm{cm}$ in-row spacing.

Pruning three to four lateral shoots from the base of staked, determinate tomatoes (Lycopersicon esculentum Mill.) increased earliness but decreased total yields compared to not pruning (Davis and Estes, 1993). For luffa, neither pruning lateral shoots nor topping the main stem had any significant effect on yields on any of the three harvest dates (Table 4). For the total season, however, no pruning produced more gourds than topping at node 6 .

Table 4. Influence of in-row spacing and pruning on total yields of luffa sponge gourds.

\begin{tabular}{|c|c|c|c|c|}
\hline \multirow[b]{3}{*}{ Main effect } & \multicolumn{4}{|c|}{ No. gourds/ha (1000s) } \\
\hline & \multicolumn{4}{|c|}{ Harvest } \\
\hline & 10 Oct. & 15 Nov. & 10 Dec. & Total \\
\hline \multicolumn{5}{|l|}{ In-row spacing $(\mathrm{cm})$} \\
\hline 30.5 & 23.5 & 18.1 & 34.2 & 75.8 \\
\hline 61 & 16.3 & 17.4 & 26.9 & 60.6 \\
\hline 91 & 17.1 & 13.0 & 24.3 & 54.4 \\
\hline $\mathrm{LSD}_{0.05}$ & 4.2 & NS & 4.3 & 5.7 \\
\hline \multicolumn{5}{|l|}{ Pruning } \\
\hline Topping at node 6 & 17.3 & 13.5 & 28.9 & 59.6 \\
\hline Removing four laterals & 18.5 & 17.9 & 28.2 & 64.6 \\
\hline No pruning & 21.1 & 17.1 & 28.4 & 66.7 \\
\hline $\mathrm{LSD}_{0.05}$ & NS & NS & NS & 5.7 \\
\hline \multicolumn{5}{|l|}{ Significance } \\
\hline In-row spacing & ** & NS & $* *$ & $* *$ \\
\hline Pruning & NS & NS & NS & $*$ \\
\hline Interaction & $*$ & NS & NS & NS \\
\hline
\end{tabular}

ss, *, ** Nonsignificant or significant at $P \leq 0.05$ or 0.01 , respectively.

Table 5. Influence of in-row spacing and pruning on marketable yields and percent culls of luffa sponge gourds.

\begin{tabular}{|c|c|c|c|}
\hline $\begin{array}{l}\text { In-row } \\
\text { spacing (cm) }\end{array}$ & Pruning & $\begin{array}{c}\text { Marketable yield } \\
\text { (no./ha, 1000s) }\end{array}$ & $\begin{array}{c}\text { Culls } \\
\text { (\% total) }\end{array}$ \\
\hline \multirow[t]{3}{*}{30.5} & Topping at node 6 & $5 \overline{7.2}$ & 15 \\
\hline & Removing four laterals & 76.9 & 5 \\
\hline & No pruning & 67.9 & 13 \\
\hline \multirow[t]{3}{*}{61} & Topping at node 6 & 53.6 & 7 \\
\hline & Removing four laterals & 58.8 & 5 \\
\hline & No pruning & 58.3 & 6 \\
\hline \multirow[t]{3}{*}{91} & Topping at node 6 & 49.1 & 8 \\
\hline & Removing four laterals & 43.7 & 13 \\
\hline & No pruning & 56.1 & 6 \\
\hline $\mathrm{LSD}_{0.05}$ for interaction & & 10.3 & 8 \\
\hline \multicolumn{4}{|l|}{ Significance } \\
\hline In-row spacing & & $* *$ & NS \\
\hline Pruning & & $*$ & NS \\
\hline Interaction & & $*$ & $*$ \\
\hline
\end{tabular}

Ns. ${ }^{*}{ }^{* *}$ Nonsignificant or significant at $P \leq 0.05$ or 0.01 , respectively.
Some gourds were badly deformed or curved, or the sponge was discolored. Those gourds were classified as culls and discarded; the remaining gourds were classified as marketable (Table 5). There was a spacing $x$ pruning interaction for both percent culls and marketable yield. When the main stem was topped at node 6 or the plants were not pruned, percentage of culls was high at the $30.5-\mathrm{cm}$ inrow spacing and low at the two wider spacings. In contrast, when the first four lateral shoots were removed, percentage of culls was highest at the widest spacing. For all pruning treatments, marketable yields decreased as inrow spacing increased. This decrease, however, was most dramatic for plants with the first four laterals removed; those plants had the highest marketable yields at $30.5-\mathrm{cm}$ inrow spacing and the lowest ones at $91-\mathrm{cm}$ inrow spacing.

Spacing and pruning also influenced gourd size. Average gourd diameter and length increased as in-row spacing increased (Table 6). Response of gourd length to in-row spacing was similal to results reported by Ko et al. (1978). In their study, average gourd lengths obtained with 90 - to $60-\mathrm{cm}$ in-row spacings were 44 and $43 \mathrm{~cm}$, respectively. In comparison, average gourd lengths in this study were 42.7 and $42.2 \mathrm{~cm}$ for $91-$ and $61-\mathrm{cm}$ in-row spacings, respectively.

Pruning had no effect on average sponge diameter, but topping the plants produced the longest sponges (Table 6). Neither spacing nor pruning had any effect on yields of largediameter sponges (7.7-10.2 cm). However, a higher percentage of the total yield fit this size category when plants were spaced $91 \mathrm{~cm}$ apart (61\%) vs. when plants were spaced $30.5 \mathrm{~cm}$ apar (41\%). In contrast, yields of bath sponges (5.1 to $7.6 \mathrm{~cm}$ in diameter) were highest at the closest spacing. The most useful sponges are generally $5.1-10.2 \mathrm{~cm}$ in diameters and are $15.2-45.7 \mathrm{~cm}$ long. Plants in the $30.5-\mathrm{cm}$ inrow spacing produced the highest yields of sponges $5.1-7.6 \mathrm{~cm}$ in diameter, $15.2-30.5 \mathrm{~cm}$ long, and 30.6-45.7 cm long. Pruning treatment had no effect on these size categories.

Sponge quality was evaluated using characteristics important to buyers. The importance of a characteristic depends on the final use of the sponge. For example, a very dense network of fibers is needed for bath sponges, whereas a less dense network of fibers is needed for pot scrubbers. Overall fiber density and visual appeal ratings were highest with sponges from plants spaced $91 \mathrm{~cm}$ apart (Table $6)$. Fiber density was lowest for sponges from plants spaced $30.5 \mathrm{~cm}$ apart, and visual appeal ratings were lowest for sponges from plants spaced $61 \mathrm{~cm}$ apart. Topping the main stem produced sponges with the best fiber density, strength, and visual appeal ratings. In contrast, not pruning resulted in sponges with the lowest ratings for all three characteristics.

Results from this study indicate that high yields of quality luffa sponges can be produced in a cool, temperate climate if transplants are field set immediately after the danger of frost has past. High total yields were obtained by using a close in-row spacing (30.5 
Crop Production

Table 6. Influence of in-row spacing and pruning on length and diameter of luffa sponge gourds.

\begin{tabular}{|c|c|c|c|c|c|c|c|c|c|}
\hline \multirow[b]{3}{*}{ Main effect } & \multicolumn{2}{|c|}{ Mean } & \multicolumn{4}{|c|}{ No. gourds/ha (1000s) } & \multicolumn{3}{|c|}{ Quality attributes } \\
\hline & \multirow{2}{*}{$\begin{array}{l}\text { Diam } \\
(\mathrm{cm})\end{array}$} & \multirow{2}{*}{$\begin{array}{c}\text { Length } \\
(\mathrm{cm})\end{array}$} & \multicolumn{2}{|c|}{$\operatorname{Diam}(\mathrm{cm})$} & \multicolumn{2}{|c|}{ Length $(\mathrm{cm})$} & \multirow{2}{*}{$\begin{array}{c}\text { Fiber } \\
\text { density }^{2}\end{array}$} & \multicolumn{2}{|c|}{ Sponge } \\
\hline & & & $5.1-7.6$ & $7.7-10.2$ & $15.2-30.5$ & $30.6-45.7$ & & Strength $^{y}$ & Appearance $^{x}$ \\
\hline \multicolumn{10}{|l|}{ In-row spacing $(\mathrm{cm})$} \\
\hline 30.5 & 7.9 & 39.9 & 36.2 & 31.2 & 10.7 & 42.6 & 2.4 & 2.2 & 2.6 \\
\hline 61 & 8.3 & 42.2 & 24.0 & 32.4 & 7.4 & 31.7 & 2.6 & 2.3 & 2.4 \\
\hline 91 & 8.6 & 42.7 & 15.7 & 33.7 & 4.1 & 28.8 & 2.9 & 2.6 & 2.9 \\
\hline $\mathrm{LSD}_{0.05}$ & 0.02 & 1.5 & 5.9 & NS & 3.0 & 5.8 & 0.4 & NS & 0.4 \\
\hline \multicolumn{10}{|l|}{ Pruning } \\
\hline Topping at node 6 & 8.3 & 42.7 & 22.1 & 30.9 & 5.5 & 31.0 & 3.0 & 3.0 & 2.9 \\
\hline Removing four laterals & 8.2 & 40.6 & 28.6 & 31.1 & 8.5 & 37.2 & 2.6 & 2.0 & 2.6 \\
\hline No pruning & 8.3 & 41.6 & 25.2 & 35.3 & 8.1 & 34.8 & 2.3 & 2.1 & 2.4 \\
\hline $\operatorname{LSD}_{0.05}$ & NS & 1.5 & NS & NS & NS & NS & 0.4 & 0.4 & 0.4 \\
\hline \multicolumn{10}{|l|}{ Significance } \\
\hline In-row spacing & $* *$ & $* *$ & $* *$ & NS & $* *$ & $* *$ & $*$ & NS & $*$ \\
\hline Pruning & NS & * & NS & NS & NS & NS & $* *$ & $* *$ & $*$ \\
\hline Interaction & NS & NS & NS & NS & NS & $*$ & NS & NS & NS \\
\hline
\end{tabular}

${ }^{2}$ Overall fiber density rated on a scale of 1 to 5 ( 1 = very loose, open weave of fibers through which newspaper print could be read; $5=$ very close woven fibers that allowed little light to penetrate).

${ }^{y}$ Sponge strength was rated on a scale of 1 to $5(1=$ crumbled easily, $2=$ did not crumble but could be pulled apart, $3=$ took some effort to pull apart, $4=$ was very difficult to pull apart, and $5=$ could not be pulled apart).

${ }^{x}$ Visual appeal was rated on a scale of 1 to $5(1=$ poor with loose, broken, uneven fibers; $3=$ looked good with fairly close woven, even fibers; $5=$ excellent with very close woven, even fibers and a smooth finish).

Ns, * *** Nonsignificant or significant at $P \leq 0.05$ or 0.01 , respectively.

$\mathrm{cm}$ ) and by either not pruning plants or just removing the first four lateral shoots. Plants spaced $30.5 \mathrm{~cm}$ apart in the row with the first four lateral shoots removed produced the highest marketable yields. Plants spaced $91 \mathrm{~cm}$ apart in the row produced the largest diameter gourds, whereas plants with the highest yields of bath-sponge-diameter gourds $(5.1-7.6 \mathrm{~cm})$ were spaced $30.5 \mathrm{~cm}$ apart in the row. By planting at the widest spacing and topping the main stem, plants obtained high fiber density, strong fibers, and excellent visual appeal. Those treatments also, however, resulted in the lowest yields. Spacing plants $30.5 \mathrm{~cm}$ apart and removing the first four lateral shoots produced sponges with a medium fiber density and good visual appeal-probably suitable for bath sponges. Further studies on sponge quality, grading standards, and market needs are required.

The question remains whether luffa sponge gourds produced in North America can be competitive with the Asian and South American imports. Economics of production are not yet known and labor costs may be high, but yields appear to be favorable; the highest total yield obtained in this study was $\approx 77,00$ gourds/ ha, which is $\approx 1$.6times greater than the highest yield reported in a Korean study (Ko et al., 1978).

\section{Literature Cited}

Bai, X.L., X.F. Ma, M.L. Xu, and X. Hou. 1985. Influence of fruit-setting time on Luffs cylindrica yield (in Chinese). Shanxi Agr. Sci. 11:6-7. Inst. of Medicine, Taiyuan, Shanxi, China. (Hort. Abstr. 56:1139; 1986).

Byrd, T.M. and J.R. Christensen (eds.). 1988. North Carolina agriculture from the mountains to the sea. North Carolina Assn. County Agricultural Agents, Charlotte.

Davis, J.M. and C.D. DeCourley. 1993. Luffa sponge gourds: A potential crop for small farms, p. 560 561. In: J. Janick and J.E. Simon (eds.). New crops. Wiley, New York.

Davis, J.M. and E.A. Estes. 1993. Spacing and pruning affect growth, yield and economic returns of staked fresh-market tomatoes. J. Amer. Soc. Hort. Sci. 118:719-725.

Dubey, K.C. 1983. Effect of ethrel, naphthaleneacetic acid and maleic hydrazide on growth, flowering and yield of sponge-gourd. Indian J. Agr. Sci. 53(6):437-441.

Hanna, H.Y., A.J. Adams, and R.N. Story. 1987. Increased yield in slicing cucumbers with vertical training of plants and reduced plant spacing. HortScience 22:32-34.

Johnson, W.B. 1984. Luffa-vegetable sponge or dishcloth gourd: How to grow and prepare it for use. no. 59. New Jersey Coop. Ext. Serv., Cook College, New Brunswick, N.J.

Ko, B.R., K.B. Lee, J.S. La, S.P. Nho, and D.K. Lee. 1978. Studies on the effect of planting density and level of fertilizer to the growth of $L u f f a$ cylindrica Roemer gourds (in Korean). Nongsa Silhom Yon'gu Pogo. Res. Rpt. 20:47-50.

Okusanya, O.T. 1978. The effects of light and temperature on germination and growth of Luffa aegyptiaca. Physiol. Plant. 44:429-433.

Okusanya, O.T. 1983a. Experimental studies on some observed variations in Luffa aegyptiaca. Can. J. Bot. 61:202-210.

Okusanya, O.T. 1983b. The mineral nutrition of Luffa aegyptiaca, Can. J. Bot. 61:2124-2131.

Okusanya, O.T., L.E. Edet, and O.O. Lakanmi. 1988. Effects of pre-planting, mixed planting and planting density of Vigna unguiculata (L.) Walp. on the growth of Luffa aegyptiaca Mill. in humic and red lateritic soils. Trop. Agr. (Trinidad) 65(3):241-244.

Okusanya, O.T. and 0.0. Lakanmi. 1985. The growth of Luffa aegyptiaca in response to various nitrogen sources and concentrations. Can. J. Bot. 63:2283-2287.

Okusanya, O.T., B.A. Ola-Adams, and J.F. Bamidele. 1981. Variations in size, leaf morphology, and fruit characters among 25 populations of Luffa aegyptiaca. Can. J. Bot. 59:2618-2627.

Omini, M.E. and M.G. Hossain. 1987. Modification of sex expression in sponge gourd (Luffa cylindrica L.) Roem by mineral nutrient treatments. Genetics 74:203-209.

Porterfield, W.M. 1955. Loofah: The sponge gourd. Econ. Bot. 9:211-223.

Russo, M.M., B.W. Roberts, and R.J. Schatzer. 1991. Feasibility of trellised cucumber production. HortScience 26:1156-1158.

Shah, J.J., Y.J. Thanki, and I.L. Kothari. 1980. Skeletal fibrous net in fruits of Luffa cylindrica M. Roem, and Luffa acutangula Roxb., p. 6172. In: M. Nagaraj and C.P. Malik (eds.). Current trends in botanical research. Kalyani Publishers, New Delhi.

Singh, K., R.N. Vashistha, M.L. Pandita, and B.R. Batra. 1976. Effect of mulching on growth and yield of cucurbits under rainfed conditions. Haryana J. Hort. Sci. 5(1\&2):87-91.

Sinnott, E.W. and R. Bloch. 1943, Luffa sponges, a new crop for the Americas. J. New York Bot. Garden 44(522): 125-132.

Stephens, J.M. 1988. Gourd, luffa, p. 51. In: Manual of minor vegetables. Florida Coop. Ext. Serv., Univ. of Florida, Bul. SP-40.

Takahashi, H. 1980. Sex expression as affected by $\mathrm{N}^{6}$-benzylaminopurine in staminate inflorescence of Luffa cylindrica. Plant \& Cell Physiol. 21:525-536.

Whitaker, T.W. 1977. Cucurbit crops-cucumber, gourds, melons, pumpkins, squash-have uniform needs, p. 187-195. In: J. Hayes (ed.). Gardening for food and fun: U.S. Dept. of Agr. yearbook of agriculture. U.S. Govt. Printing Office, Washington, D.C. 